\title{
Microbial iron(II) oxidation in littoral freshwater lake sediment: the potential for competition between phototrophic vs. nitrate-reducing iron(II)-oxidizers
}

\author{
E. D. Melton, C. Schmidt and A. Kappler* \\ Geomicrobiology, Centre for Applied Geosciences, University of Tübingen, Tübingen, Germany
}

\section{Edited by:}

David Emerson, Bigelow Laboratory

for Ocean Sciences, USA

\section{Reviewed by:}

Evgenya Shelobolina, University of Wisconsin-Madison, USA

Sean Crowe, University of Southern Denmark, Denmark

\section{*Correspondence:}

A. Kappler, Geomicrobiology, Center for Applied Geosciences, University of Tübingen, Sigwartstraße 10,

D-72076 Tübingen, Germany.

e-mail: andreas.kappler@

uni-tuebingen.de
The distribution of neutrophilic microbial iron oxidation is mainly determined by local gradients of oxygen, light, nitrate and ferrous iron. In the anoxic top part of littoral freshwater lake sediment, nitrate-reducing and phototrophic Fe(II)-oxidizers compete for the same $e^{-}$donor; reduced iron. It is not yet understood how these microbes co-exist in the sediment and what role they play in the Fe cycle. We show that both metabolic types of anaerobic Fe(II)-oxidizing microorganisms are present in the same sediment layer directly beneath the oxic-anoxic sediment interface. The photoferrotrophic most probable number counted $3.4 \cdot 10^{5}$ cells $\cdot \mathrm{g}^{-1}$ and the autotrophic and mixotrophic nitrate-reducing $\mathrm{Fe}\left(\mathrm{II}\right.$ )-oxidizers totaled $1.8 \cdot 10^{4}$ and $4.5 \cdot 10^{4}$ cells $\cdot \mathrm{g}^{-1}$ dry weight sediment, respectively. To distinguish between the two microbial Fe(II) oxidation processes and assess their individual contribution to the sedimentary Fe cycle, littoral lake sediment was incubated in microcosm experiments. Nitrate-reducing Fe(II)-oxidizing bacteria exhibited a higher maximum $\mathrm{Fe}(\mathrm{II})$ oxidation rate per cell, in both pure cultures and microcosms, than photoferrotrophs. In microcosms, photoferrotrophs instantly started oxidizing Fe(II), whilst nitrate-reducing $\mathrm{Fe}(\mathrm{II})$-oxidizers showed a significant lag-phase during which they probably use organics as $\mathrm{e}^{-}$donor before initiating Fe(II) oxidation. This suggests that they will be outcompeted by phototrophic Fe(II)-oxidizers during optimal light conditions; as phototrophs deplete Fe(II) before nitrate-reducing Fe(II)-oxidizers start Fe(II) oxidation. Thus, the co-existence of the two anaerobic Fe(II)-oxidizers may be possible due to a niche space separation in time by the day-night cycle, where nitrate-reducing Fe(II)-oxidizers oxidize Fe(II) during darkness and phototrophs play a dominant role in Fe(II) oxidation during daylight. Furthermore, metabolic flexibility of $\mathrm{Fe}(\mathrm{II})$-oxidizing microbes may play a paramount role in the conservation of the sedimentary Fe cycle.

Keywords: photoferrotrophs, nitrate-reducing Fe(II)-oxidizers, freshwater littoral sediment, microcosms, competition

\section{INTRODUCTION}

Iron is a ubiquitously abundant redox active transition metal in sedimentary systems (Froelich et al., 1979; Canfield et al., 1993). Not only is it required for integral components in cellular processes in many eukaryotic and prokaryotic organisms, but it can also serve as an electron donor or acceptor to many prokaryotes (Kappler and Straub, 2005; Weber et al., 2006a; Konhauser et al., 2011). Particularly, in freshwater lakes with low sulfate concentrations, microbial Fe(III) reduction is an important process in the anaerobic degradation of organic matter (Thamdrup, 2000; Lovley et al., 2004). Freshwater lakes cover approximately $0.8 \%$ of the Earth's surface (Dudgeon et al., 2006) and their iron rich redox stratified sediment provides the ideal habitat for Fe-metabolizing bacteria.

$\mathrm{Fe}(\mathrm{III})$ and other oxidants in the pore water of the sediment are consumed by bacterial processes in a hierarchical order of decreasing energy production per mole of organic carbon oxidized (Froelich et al., 1979; Canfield and Thamdrup, 2009). This creates a chemical gradient within the sediment column, which describes a defined sequence of redox zones in these sediments that are individually characterized by the dominantly consumed electron acceptor. The dominant electron acceptor in the first layer is oxygen, which is defined as the oxic zone (Froelich et al., 1979; Canfield and Thamdrup, 2009). Once oxygen is depleted, and the redox potential is driven low enough, the next most advantageous oxidants will take over. Following the depth profile: nitrate is followed by manganese, next by ferric iron, then sulfate, and finally by carbon dioxide (Froelich et al., 1979). This sequence remains unchanged throughout profundal and littoral lake sediment. However, exposure to light of the littoral sediment stimulates photosynthesis and $\mathrm{O}_{2}$ production and thus creates a downward shift, or broadening, in the spatial positioning of the redox zones (Gerhardt et al., 2005, 2010).

In contrast to electron acceptors such as oxygen, nitrate, or sulfate, ferric iron is poorly soluble, and swiftly precipitates into iron(III) (oxyhydr)oxides (Cornell and Schwertmann, 2003) which can subsequently either be reduced through chemical 
reactions (Canfield, 1989) or by microbes through organic matter or dihydrogen oxidation (Lovley and Phillips, 1988; Bonneville et al., 2004; Macdonald et al., 2011). The produced ferrous iron is more soluble (Cornell and Schwertmann, 2003) and diffuses upward through the pore water toward the oxic zone, serving as a profitable electron donor to $\mathrm{Fe}(\mathrm{II})$-oxidizing microbial communities.

Iron(II)-oxidizing bacteria have been found in high numbers in many freshwater lakes and sediments (Straub and BuchholzCleven, 1998; Diez et al., 2007). Three types of neutrophilic bacteria complete the oxidation part of the freshwater sedimentary iron redox cycle: microaerophiles (Emerson and Moyer, 1997), nitrate-reducing Fe(II)-oxidizers (Straub et al., 1996), and photoferrotrophs (Widdel et al., 1993; Ehrenreich and Widdel, 1994). As microbial iron oxidation products have been found to suitably serve as substrate for iron(III)-reducing bacteria (Emerson and Moyer, 1997; Straub and Buchholz-Cleven, 1998; Bloethe and Roden, 2009a), it is feasible that these oxidizing and reducing communities successfully support a sedimentary iron redox cycle. Their close physical proximity and co-existence in the redox zones of the sediment further supports the presence of a microbial iron redox cycle (Sobolev and Roden, 2002; Bruun et al., 2010), which has also evoked the formulation of a conceptual model for the spatial niche separation for iron metabolizers in the iron cycle (Schmidt et al., 2010). Furthermore, artificial Fe redox cycles in laboratory settings have been successfully achieved at neutral $\mathrm{pH}$ through co-cultures of $\mathrm{Fe}(\mathrm{III})$-reducing and Fe(II)-oxidizing bacteria (Straub et al., 2004; Coby et al., 2011).

Neutrophilic nitrate-reducing Fe(II)-oxidizers have been found in high numbers in many freshwater lakes and sediments (Hauck et al., 2001; Muehe et al., 2009) and produce poorly crystalline $\mathrm{Fe}$ (III) hydroxides (ferrihydrite) or more crystalline Fe(III) oxyhydroxides (goethite, lepidocrocite) as their Fe(II) oxidation product (Straub et al., 2004; Kappler et al., 2005b; Larese-Casanova et al., 2010). Their metabolism adheres to the following stoichiometric equation: $10 \mathrm{Fe}^{2+}+2 \mathrm{NO}_{3}^{-}+24 \mathrm{H}_{2} \mathrm{O} \rightarrow 10 \mathrm{Fe}(\mathrm{OH})_{3}+\mathrm{N}_{2}+18 \mathrm{H}^{+}$ (Straub et al., 1996). Whilst the existence of autotrophic nitratereducing $\mathrm{Fe}(\mathrm{II})$-oxidizers has been suggested, to date, a true autotrophic nitrate-reducing $\mathrm{Fe}(\mathrm{II})$-oxidizer that can be successfully transferred without an organic co-substrate over many generations has not been isolated. The enrichment of a co-culture named KS has been achieved (Straub et al., 1996; Bloethe and Roden, 2009b) but so far, all pure nitrate-reducing Fe(II)-oxidizing isolates adhere to a mixotrophic metabolism, requiring the need of an organic co-substrate for Fe(II) oxidation (Straub et al., 1996; Kappler et al., 2005b; Muehe et al., 2009; Chakraborty et al., 2011). This metabolism is widespread within the denitrifying proteobacteria (Straub et al., 1996, 2004). In fact, addition of iron(II) to a denitrifying population enhances their cell growth, implying that iron(II) oxidation is truly a beneficial metabolism and $\mathrm{Fe}$ (III) is not simply a byproduct from another minor reaction mechanism (Muehe et al., 2009; Chakraborty et al., 2011). Moreover, in addition to $\mathrm{Fe}(\mathrm{II})$ oxidation, many denitrifying bacteria are also capable of switching to microaerophilic Fe(II) oxidation (Benz et al., 1998; Edwards et al., 2003). It is thus conceivable that although nitrate-reducing Fe(II) oxidation is an anaerobic metabolism, the organisms catalyzing this process may also be able to oxidize $\mathrm{Fe}(\mathrm{II})$ at oxygen levels up to $50 \mu \mathrm{M}$, like other known microaerophilic Fe(II)-oxidizers (Druschel et al., 2008).

Photosynthetic $\mathrm{Fe}(\mathrm{II})$ oxidation can only take place during daylight hours, as starlight and even a full moon fail to provide adequate light to support photosynthetic microbial growth (Raven and Cockell, 2006). During daylight hours, light has been shown to penetrate through sediment up until a depth of at least 5-6 mm (Kuehl et al., 1994). As well as being reflected by reflective particles, light is scavenged in the sediment, dramatically decreasing its intensity with depth toward an asymptotic value, posing a potential problem for photoferrotrophs living beneath the oxygen penetration depth (Kuehl et al., 1994). Nevertheless, photoferrotrophs are reasonably widespread in freshwater systems, having been found in freshwater lakes (Straub and Buchholz-Cleven, 1998), and isolated from numerous freshwater sediments (Widdel et al., 1993; Ehrenreich and Widdel, 1994; Heising et al., 1999). Photoferrotrophy is an anaerobic process which requires both light and bicarbonate: $\mathrm{HCO}_{3}^{-}+4 \mathrm{Fe}^{2+}+10 \mathrm{H}_{2} \mathrm{O} h v \mathrm{CH}_{2} \mathrm{O}+4 \mathrm{Fe}(\mathrm{OH})_{3}+7 \mathrm{H}^{+}$(Widdel et al., 1993). Thus, photoferrotrophs are most probably spatially restricted by the sedimentary chemocline, the light penetration depth and upward Fe(II) diffusion from the deeper sediment layers. Only dissolved ferrous iron is susceptible to phototrophic $\mathrm{Fe}$ (II) oxidation and the oxidation products are poorly crystalline $\mathrm{Fe}$ (III) oxides (Kappler and Newman, 2004). The genetic heritage of anoxygenic phototrophs has been traced back to the oldest photosynthetic lineage (Xiong et al., 2000), and photoferrotrophs are able to thrive in archaean ocean analogs (Crowe et al., 2008). Thus, it has been proposed that anoxygenic photoferrotrophy played a paramount role in the deposition of Precambrian banded iron formations (Konhauser et al., 2002; Kappler et al., 2005a; Crowe et al., 2008; Posth et al., 2008).

As both photoferrotrophic and nitrate-reducing Fe(II) oxidation are anaerobic metabolisms, the habitat of the microorganisms catalyzing these processes is likely to be restricted to the same top anoxic part of the sediment where incidentally the local geochemical gradients of $\mathrm{Fe}(\mathrm{II})$, oxygen, nitrate and sunlight provide optimal living conditions for both. This means that their growth, and co-existence, depends on their successful competition for reduced iron. Many previous studies focus either solely on one of the iron(II)-oxidizing processes (Straub and Buchholz-Cleven, 1998; Jiao et al., 2005; Muehe et al., 2009; Poulain and Newman, 2009) or on the co-existence of $\mathrm{Fe}(\mathrm{II})$-oxidizers and $\mathrm{Fe}(\mathrm{III})$-reducers in cycling systems (Straub et al., 2004; Coby et al., 2011). So far, the spatial distribution and positioning in relation to each other specifically of phototrophic and nitrate-reducing Fe(II)-oxidizers has not yet been studied. As their habitats probably overlap significantly, they are expected to exhibit fierce competition for Fe(II). However, the individual contributions of photoferrotrophs and nitrate-reducing $\mathrm{Fe}$ (II)-oxidizers to iron(II) oxidation, and hence their competition for ferrous iron has also not been previously studied. Therefore, the objectives of this study were firstly: to determine whether both phototrophic and nitrate-reducing anaerobic Fe(II)-oxidizing bacteria are present in the same sediment layer directly beneath the oxic-anoxic boundary, and secondly: what their individual contribution is to sedimentary Fe(III) formation. We also explored geochemical factors that could limit iron(II) oxidation by the two anaerobic Fe(II)-oxidizing groups, 
and how they compete with one another for ferrous iron. These experiments combine microbial and geochemical techniques to provide key information needed not only to determine the contribution of microbial activity to the overall iron oxidation budget and their spatial distribution, but also to define the role of geo/photochemical iron conversion rates and its general importance in littoral freshwater lake sediment.

\section{MATERIALS AND METHODS SAMPLING SITE AND INITIAL SAMPLE TREATMENT}

Littoral sediment and water samples were taken in February 2011 from Lake Constance, a freshwater lake in southern Germany, at a location in the north-western arm known as the Überlingersee, near the island of Mainau at $47^{\circ} 41^{\prime} 42.63^{\prime \prime} \mathrm{N}$ and $9^{\circ} 11^{\prime} 40.29^{\prime \prime} \mathrm{E}$. The samples were transported to the laboratory at $4^{\circ} \mathrm{C}$ and the sediment was processed immediately for microelectrode analysis, most probable number (MPN) studies and microcosm incubations.

A high-resolution oxygen microelectrode profile was taken from an intact push-core immediately upon arrival in the laboratory (within $2 \mathrm{~h}$ of sampling during which time it was stored under darkness) with a Unisense Clark-type oxygen microelectrode with a tip diameter of $100 \mu \mathrm{m}$. The electrode was two-point calibrated in air-saturated water and anoxic water. The detection limit was $0.3 \mu \mathrm{mol} \cdot \mathrm{L}^{-1}$. Measurements were taken with a micromanipulator at depth intervals of $500 \mu \mathrm{m}$.

The water content of littoral sediment was determined in triplicate by weighing portions of wet sediment, drying them for 4 days at $95^{\circ} \mathrm{C}$, and subsequently determining the dry weight. Dried samples were pulverized to fine powder from which the percentage of iron by weight was determined using X-ray fluorescence analysis (XRF) employing a Bruker AXS S4 Pioneer X-ray fluorescence spectrometer. The dissolved organic carbon (DOC) and total inorganic carbon (TIC) content of the pore water were determined from a centrifuged portion of wet sediment, of which the supernatant was subsequently filtered with a $0.45 \mu \mathrm{m}$ filter (mixed esters of cellulose nitrate and acetate membrane). DOC and TIC of the water overlying the surface of the sediment was determined from filtrated water $(0.45 \mu \mathrm{m}$, mixed esters of cellulose nitrate and acetate membrane). Samples were then analyzed in a High TOC Elementar instrument. The aqueous ferrous iron concentration ( $\mu$ moles $\cdot \mathrm{L}^{-1}$ ) was measured from the pore water by the spectrophotometric ferrozine assay (Stookey, 1970) in a Flashscan 550 microplate reader, Analytik Jena AG, Germany with a 5\% error.

\section{SET-UP OF MICROCOSM INCUBATIONS}

Lake water for the microcosm experiments was purged with $\mathrm{N}_{2}$ gas for $1 \mathrm{~h}$ and buffered with $20 \mathrm{mM} 3-(N-$ morpholino)propanesulfonic acid (MOPS) buffer, with the exception of set-ups with bicarbonate amendment which were buffered with $10 \mathrm{mM}$ bicarbonate buffer, and filtered sterilely $(0.22 \mu \mathrm{m}$, mixed ester cellulose membrane) under a $\mathrm{N}_{2}$ atmosphere in a glovebox. The $\mathrm{pH}$ of the water was adjusted with sterile anoxic $1 \mathrm{M} \mathrm{HCl}$ to 7.20 , which was the $\mathrm{pH}$ measured in the natural lake water before purging.

Hundred milliliter serum bottles were filled with $1 \mathrm{~g}$ of wet sediment and $50 \mathrm{~mL}$ lake water (natural water, not medium, to stay as close as possible to in situ conditions), sealed with a butyl rubber stopper and crimped. The headspace was replaced by $\mathrm{N}_{2} / \mathrm{CO}_{2}$ (90:10) gas. One set-up contained only pure sediment and water, whilst the other set-ups contained an amendment including: $4 \mathrm{mM}$ $\mathrm{NO}_{3}^{-}$or $10 \mathrm{mM} \mathrm{Fe}^{2+}$ or $10 \mathrm{mM} \mathrm{Fe}^{2+}$ and $10 \mathrm{mM} \mathrm{HCO}_{3}^{-}$. Additionally, each set-up included a sterile set of duplicates by anoxic $\mathrm{NaN}_{3}$ addition (the final concentration was $160 \mathrm{mM}$ ). All microcosms were set-up in duplicate at $23^{\circ} \mathrm{C}$, of which one set was incubated under constant light (True Light $15 \mathrm{~W} / 5500 \mathrm{~K}$ ) and the other in constant darkness, for 30 days. The light incubations facilitated both phototrophic and nitrate-reducing iron(II)-oxidizers whilst the dark incubation only permitted nitrate-reducing iron(II)oxidizers to oxidize $\mathrm{Fe}(\mathrm{II})$. This allows a distinction between the two microbial anaerobic iron(II) oxidation processes.

\section{ANALYSIS OF MICROCOSM INCUBATIONS}

Two milliliters were sampled from each microcosm at each sampling point under a constant $\mathrm{N}_{2}$ atmosphere in an anoxic glovebox, without opening the bottles, with a sterile anoxic syringe and needle (inner diameter of $0.80 \mathrm{~mm}$ ). These $2 \mathrm{~mL}$ samples were centrifuged for $5 \mathrm{~min}$ at $15.4 \mathrm{~g}$. Part of the supernatant was stabilized in $1 \mathrm{M} \mathrm{HCl}$ and used for the spectrophotometric ferrozine assay (Stookey, 1970) to quantify dissolved $\mathrm{Fe}(\mathrm{II}) / \mathrm{Fe}$ (total) in $\mu$ moles $\cdot \mathrm{L}^{-1}$ which was then recalculated to the absolute amount per microcosm; another part was frozen anoxically at $-20^{\circ} \mathrm{C}$ and preserved for dissolved $\mathrm{NO}_{3}^{-} / \mathrm{NO}_{2}^{-}$measurement by a flow injection analysis (FIA) system (3-QuAAtro, Bran\&Lübbe, Norderstedt, Germany) which exhibited an error of $3.6 \cdot 10^{-3} \mathrm{~mol} \cdot \mathrm{N} \cdot \mathrm{L}^{-1}$. The sediment pellet was further incubated anoxically for $1 \mathrm{~h}$ on a horizontal shaker at $150 \mathrm{rpm}$ with $0.5 \mathrm{M} \mathrm{HCl}$ in order to extract the poorly crystalline $\mathrm{Fe}(\mathrm{II}) / \mathrm{Fe}$ (total) fraction, which was quantified from the supernatant by the spectrophotometric ferrozine assay (Stookey, 1970) in $\mu$ moles $\cdot \mathrm{L}^{-1}$ which was then recalculated to the absolute amount per microcosm.

\section{MOST PROBABLE NUMBER QUANTIFICATION OF Fe(II)-OXIDIZING MICROORGANISMS}

The $3 \mathrm{~mm}$ sediment layer right below the oxic/anoxic boundary, defined by microelectrode measurements, was sampled under air using a subcore slicer (Gerhardt et al., 2005) and homogenized inside an anoxic glovebox. The subcore slicer allows sampling at a resolution of $1 \mathrm{~mm}$ by pushing the sediment out of the plexiglass core in 1-mm steps. From this homogenized wet sediment $1 \mathrm{~mL}$ was inoculated anoxically into a tube containing $9 \mathrm{~mL}$ of $22 \mathrm{mM}$ bicarbonate buffered non-amended freshwater medium with a $\mathrm{pH}$ of 7.17 (modified from Hegler et al., 2008; Ehrenreich and Widdel, 1994 containing $0.6 \mathrm{~g} \cdot \mathrm{L}^{-1} \mathrm{KH}_{2} \mathrm{PO}_{4}, 0.3 \mathrm{~g} \cdot \mathrm{L}^{-1} \mathrm{NH}_{3} \mathrm{Cl}, 0.5 \mathrm{~g} \cdot \mathrm{L}^{-1}$ $\mathrm{MgSO}_{4} \cdot \mathrm{H}_{2} \mathrm{O}, 0.1 \mathrm{~g} \cdot \mathrm{L}^{-1} \mathrm{CaCl}_{2} \cdot 2 \mathrm{H}_{2} \mathrm{O}$ ). From this a 10 -fold dilution series into subsequent medium tubes was prepared anoxically $\left(10^{-1}\right.$ to $\left.10^{-12}\right)$ and inoculated into deep well plates containing medium targeting specifically: photoferrotrophic $(22 \mathrm{mM}$ bicarbonate buffered $10 \mathrm{mM} \mathrm{Fe}^{2+}$ (before filtration) filtered freshwater medium), mixotrophic nitrate-reducing iron-oxidizing $(22 \mathrm{mM}$ bicarbonate buffered freshwater medium with $10 \mathrm{mM} \mathrm{Fe}^{2+}, 4 \mathrm{mM}$ $\mathrm{NO}_{3}^{-}$and $0.5 \mathrm{mM}$ acetate) and autotrophic nitrate-reducing ironoxidizing ( $22 \mathrm{mM}$ bicarbonate buffered freshwater medium with $10 \mathrm{mM} \mathrm{Fe}^{2+}$ and $4 \mathrm{mM} \mathrm{NO}_{3}^{-}$) bacterial groups. Deep well plates were incubated anoxically at $23^{\circ} \mathrm{C}$ for 8 weeks. Positive wells were 
significantly optically darker than negative wells. Results were analyzed using the KLEE software program (Klee, 1993). Three portions from the remaining sediment were weighed and dried for 4 days at $95^{\circ} \mathrm{C}$ and weighed again for pore water determination.

\section{Fe(II) OXIDATION RATE CALCULATIONS}

The maximum $\mathrm{Fe}$ (II) oxidation rates $\left(\nu_{\max }\right)$ in pure cultures were determined from different literature studies (Jiao et al., 2005; Hegler et al., 2008; Muehe et al., 2009) by subtracting the minimum $\mathrm{Fe}$ (II) concentration at the end of $\mathrm{Fe}$ (II) oxidation, from the maximum $\mathrm{Fe}$ (II) concentration, i.e., the concentration of iron before the initiation of $\mathrm{Fe}$ (II) oxidation, thus obtaining the total amount of $\mathrm{Fe}(\mathrm{II})$ that was oxidized $[\Delta \mathrm{Fe}(\mathrm{II})]$. This was divided by the number of days during which maximum $\mathrm{Fe}$ (II) oxidation took place $(\Delta t)$ and then further divided by the number of cells present at the inflection point of maximum $\mathrm{Fe}(\mathrm{II})$ oxidation:

$\nu_{\max }=\frac{\frac{\Delta \mathrm{Fe}(\mathrm{II})}{\Delta t}}{\text { cells inflection point }}$

The maximum Fe(II) oxidation rates per cell in the microcosm studies were determined by dividing the fastest initial Fe(II) oxidation rate by the cell numbers determined from the MPN studies. The number of cells present at the inflection point were not determined, thus for simplicity the MPN values of the cell numbers in the original sediment were used, probably slightly overestimating the oxidation rate per cell at the inflection point.

$v_{\max }=\frac{\frac{\Delta \mathrm{Fe}(\mathrm{II})}{\Delta t}}{\mathrm{MPN} \text { value }}$

\section{RESULTS}

\section{SEDIMENT CHARACTERISTICS}

Lake Constance littoral sediment was of a sandy nature without any coarse clumps or large organic material. The DOC content of the water overlying the sediment was $0.15 \mathrm{mM}$, and the TIC content was $2.45 \mathrm{mM}$. The pore water content of the sediment at a depth of 6-9 mm was $41 \%$ and had a circumneutral $\mathrm{pH}$ ranging between 7.17-7.20. The DOC of the pore water was $0.39 \mathrm{mM}$ and the TIC was $6.26 \mathrm{mM}$. The dissolved nitrate concentration in the pore water was $0.10 \mu \mathrm{M}$, and the nitrite concentration was $0.056 \mu \mathrm{M}$. The total iron content of the dry weight sediment was $1.19 \%$, as measured by XRF. The sediment pore water contained $9.8 \mu \mathrm{M} \mathrm{Fe}$ (II). A summary of all the measured geochemical parameters of the sediment can be found in Table 1 .

\section{MICROSENSOR OXYGEN PROFILE AND THE DISTRIBUTION OF Fe(II)-OXIDIZING MICROORGANISMS}

The oxygen distribution in the top $6 \mathrm{~mm}$ of the littoral Lake Constance sediment showed a stepwise decrease in $2 \mathrm{~mm}$ increments until it reached the maximum penetration depth at $6 \mathrm{~mm}$ (Figure 1A). As anaerobic iron(II)-oxidizing bacteria depend on anoxic conditions, their habitat may be restricted by the overlaying oxygen boundary zone. Therefore, the $3 \mathrm{~mm}$ of sediment directly beneath the oxygen penetration depth was inoculated in a MPN study. We found that both nitrate-reducing iron(II)-oxidizers and photoferrotrophs were present in the same
Table 1 | Geochemical parameters of littoral Lake Constance sediment (6-9 mm).

\section{Sediment characteristics}

Porewater $\mathrm{pH}$

Pore water content

Total $\mathrm{Fe}_{\text {(solid phase) }}$

$\mathrm{Fe}(\mathrm{II})_{(\mathrm{aq})}$

$\mathrm{DOC}_{\text {sediment porewater }}$

$\mathrm{DOC}_{\text {water overlying the sediment }}$

$\mathrm{TIC}_{\text {sediment porewater }}$

$\mathrm{TIC}_{\text {water overlying the sediment }}$

$\mathrm{NO}_{3(\mathrm{aq}) \text {, porewater + overlying water }}^{-}$

$\mathrm{NO}_{2}^{-}$(aq), porewater + overlying water
7.17-7.20

$41 \%$

$1.19 \%$

$9.8 \mu \mathrm{M}$

$0.39 \mathrm{mM}$

$0.15 \mathrm{mM}$

$6.26 \mathrm{mM}$

$2.45 \mathrm{mM}$

$0.10 \mu \mathrm{M}$

$0.056 \mu \mathrm{M}$
$( \pm 1 \%)$

$( \pm 2.8 \mu \mathrm{M})$

$\left( \pm 4.2 \cdot 10^{-3} \mathrm{mM}\right)$

$\left( \pm 3.3 \cdot 10^{-3} \mathrm{mM}\right)$

$\left( \pm 2.3 \cdot 10^{-2} \mathrm{mM}\right)$

$\left( \pm 3.3 \cdot 10^{-3} \mathrm{mM}\right)$

$( \pm 0.008 \mu \mathrm{M})$

$( \pm 0.001 \mu \mathrm{M})$

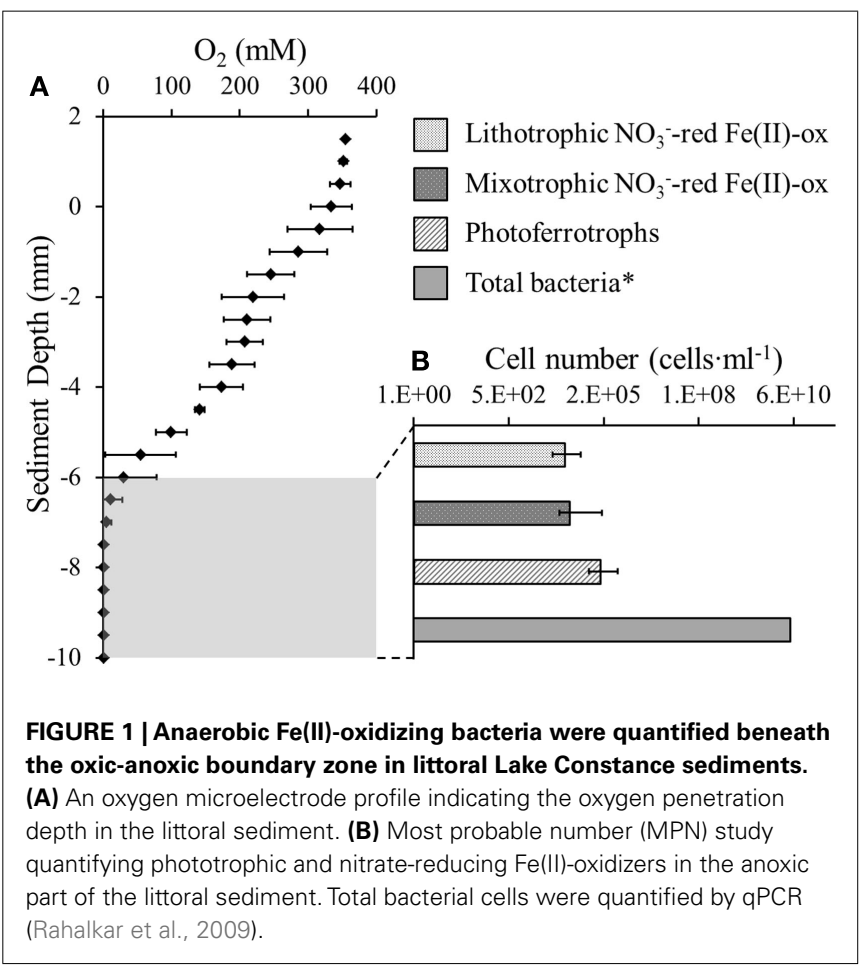

$3 \mathrm{~mm}$ segment of anoxic sediment (Figure 1B). The photoferrotrophs were slightly more abundant than the nitrate-reducing iron(II)-oxidizers at $2.0 \cdot 10^{5}$ cells $\cdot \mathrm{mL}^{-1}$ sediment. As the sediment had a pore water concentration of $41 \%$ (Table 1), this cell number corresponds to $3.4 \cdot 10^{5}$ cells. $g^{-1}$ dry weight sediment. The mixotrophic nitrate-reducing iron(II)-oxidizers were slightly more abundant than the autotrophic nitrate-reducing iron(II)-oxidizers at $2.7 \cdot 10^{4}$ and $1.9 \cdot 10^{4}$ cells $\cdot \mathrm{mL}^{-1}$, respectively, which corresponds to $4.5 \cdot 10^{4}$ and $1.8 \cdot 10^{4}$ cells. $g^{-1}$ dry weight sediment.

\section{MICROBIAL Fe(II) OXIDATION IN LITTORAL LAKE CONSTANCE SEDIMENT}

No detectable iron(II) oxidation took place in non-amended sediment microcosms incubated in the dark, neither in the microbially active nor in the sterilized set-up (Figure 2A). However, when the 


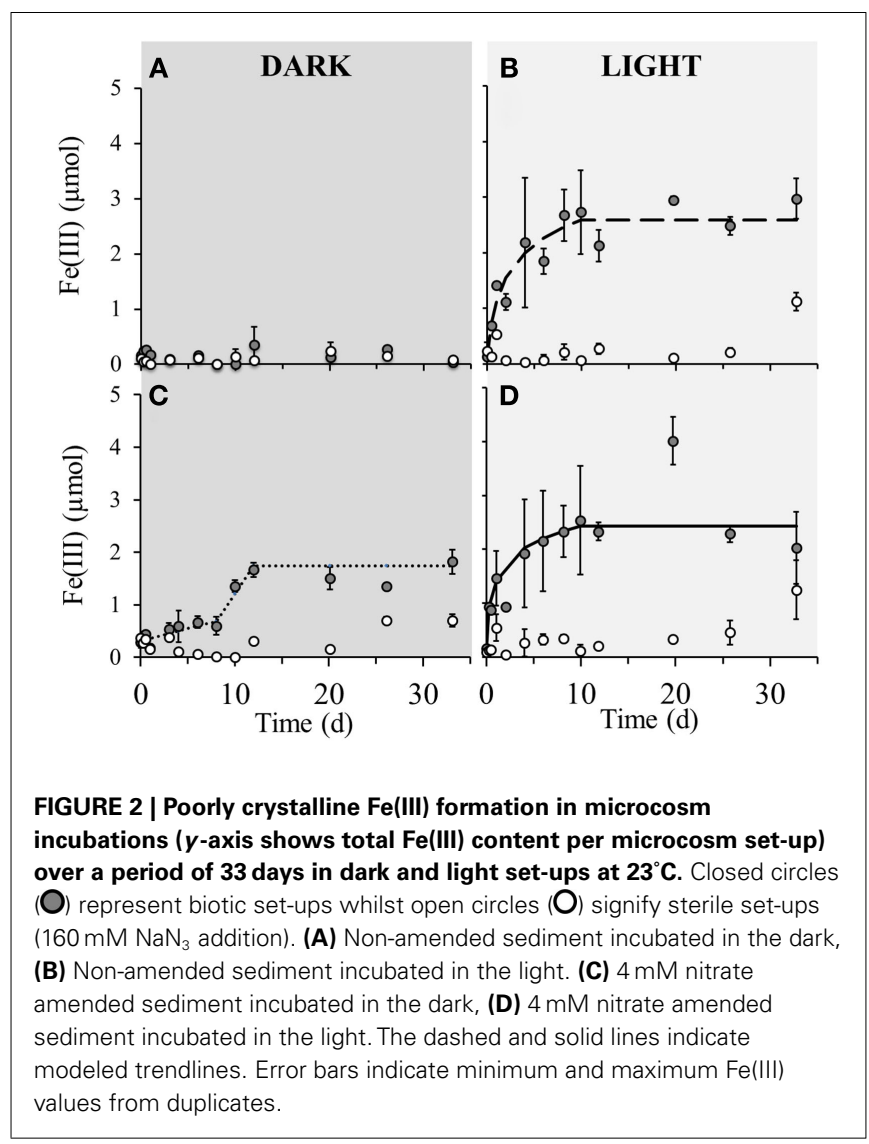

same set-up was incubated under light conditions, instant oxidation occurred in non-sterile microcosms with an initial oxidation rate of $5.4 \cdot 10^{-6} \mu \mathrm{mol} \mathrm{Fe}(\mathrm{II}) / \mathrm{cell} \cdot \mathrm{day}^{-1}$ which leveled off after approximately 8 days (Figure 2B). Sterile set-ups with light did not exhibit significant $\mathrm{Fe}$ (II) oxidation. When nitrate was added to the non-sterile sediment followed by incubation in the dark, iron(II) oxidation occurred after 8 days of incubation and ceased after around the 12th day of incubation (Figure 2C). The maximum iron(II) oxidation rate in these set-ups between days 8 and 12 was $7.1 \cdot 10^{-6} \mu \mathrm{mol} \mathrm{Fe}(\mathrm{II}) / \mathrm{cell}^{-} \cdot \mathrm{day}^{-1}$. Nitrate addition to the sediment and incubation under light conditions resulted in an instant onset of $\mathrm{Fe}(\mathrm{II})$ oxidation at a rate of $3.7 \cdot 10^{-6} \mu \mathrm{mol} \mathrm{Fe}(\mathrm{II}) / \mathrm{cell}^{-} \mathrm{day}^{-1}$ which plateaued after approximately 8 days (Figure 2D). Fe(II) oxidation in dark microcosms with addition of $\mathrm{Fe}$ (II) or $\mathrm{Fe}$ (II) and bicarbonate (but without nitrate addition) resulted in no significant $\mathrm{Fe}$ (II) oxidation in neither the microbially active nor in the sterilized set-up (Figures 3A,B). In light set-ups amended exclusively with ferrous iron, the initial $\mathrm{Fe}$ (II)-oxidation rate and extent were practically equivalent to that amended with ferrous iron and supplementary bicarbonate addition (Figure 3C).

\section{MAXIMUM Fe(II) OXIDATION RATES CALCULATED FROM PURE CULTURES AND MICROCOSMS}

Several growth experiments in the literature with different pure culture strains were investigated to calculate the maximum $\mathrm{Fe}(\mathrm{II})$ oxidation rate of several pure strains of anaerobic $\mathrm{Fe}$ (II)oxidizers. Strain BoFeN1 is a nitrate-reducing Fe(II)-oxidizing
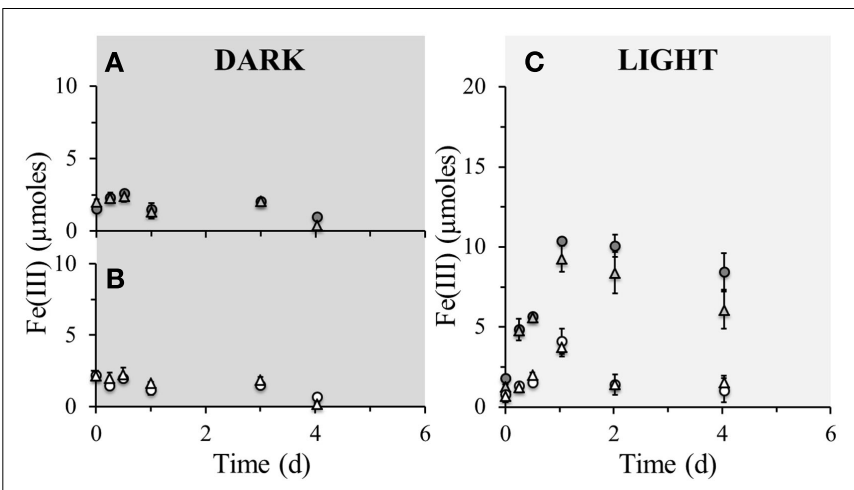

FIGURE 3 | Poorly crystalline Fe(III) formation in microcosm incubations ( $y$-axis shows total Fe(III) content per microcosm set-up) over a period of 4 days at $23^{\circ} \mathbf{C}$. Closed circles $(O)$ represent biotic set-ups with $10 \mathrm{mM} \mathrm{Fe}(\mathrm{II})$ amendment whilst open circles $(\mathbf{O})$ represent parallel sterile set-ups ( $160 \mathrm{mM} \mathrm{NaN}_{3}$ addition) with the same amendment. Closed triangles $(\Delta)$ represent biotic set-ups with $10 \mathrm{mM} \mathrm{Fe}(\mathrm{II})$ and $10 \mathrm{mM} \mathrm{HCO}_{3}^{-}$ amendment and open triangles $(\Delta)$ represent parallel sterile set-ups (160 $\mathrm{mM} \mathrm{NaN}_{3}$ addition) with the same amendments. (A) Comparison of microbially active dark set-up of solely $\mathrm{Fe}(\mathrm{II})$ amendment with $\mathrm{Fe}$ (II) and supplementary $\mathrm{HCO}_{3}^{-}$amendments. (B) Comparison of sterile dark set-up of solely $\mathrm{Fe}(\mathrm{II})$ amendment with $\mathrm{Fe}(\mathrm{II})$ and supplementary $\mathrm{HCO}_{3}^{-}$ amendments. (C) Comparison of microbially active and sterile light set-ups of solely $\mathrm{Fe}(\mathrm{II})$ amendment with $\mathrm{Fe}(\mathrm{II})$ and supplementary $\mathrm{HCO}_{3}^{-}$ amendments. Error bars indicate minimum and maximum Fe(III) values from duplicates.

$\beta$-proteobacterium from the Acidovorax genus isolated from littoral Lake Constance sediment (Kappler et al., 2005b). Growth experiments with this strain in which cell numbers and $\mathrm{Fe}(\mathrm{II})$ concentration were monitored over time (Muehe et al., 2009) provided data that allowed the maximum rate calculation for this species. Two individual photoferrotrophic strains were investigated for their maximum iron oxidation rate. The first was isolated from School Street Marsh in Woods Hole Massachusetts; Rhodopseudomonas palustris, or strain TIE-1 (Jiao et al., 2005). The second, Rhodobacter ferrooxidans sp. SW2 (Ehrenreich and Widdel, 1994) was isolated from a pond near Hanover, Germany. Growth experiments with this strain (Hegler et al., 2008) allowed the rate calculations to be made. The results are summarized in Table 2 and show an Fe(II) oxidation rate of $1.0 \cdot 10^{-8} \mu \mathrm{mol}$ $\mathrm{Fe}(\mathrm{II}) /$ cell day $^{-1}$ for the nitrate-reducing $\mathrm{Fe}(\mathrm{II})$-oxidizing strain BoFeN1 and $4.4 \cdot 10^{-10}$ and $6.6 \cdot 10^{-9} \mu \mathrm{mol} \mathrm{Fe(II)/cell \cdot day}{ }^{-1}$ for the photoferrotrophs SW2 and TIE-1, respectively.

\section{DISCUSSION SPATIAL DISTRIBUTION OF ANAEROBIC Fe(II)-OXIDIZERS IN FRESHWATER LAKE SEDIMENT}

In the littoral zone, where water levels fluctuate according to waves and wind shearing, the top layer of the sediment is subjected to irregular mechanical mixing and light irradiation (Chubarenko et al., 2003). This causes the oxygen penetration depth to vary according to these external forces exerted on the sediment and overlying water (Gerhardt et al., 2005). The oxygen penetration depth is also influenced by the ambient temperature, as the dissolution of oxygen in pore water is facilitated at lower temperatures. 
Table 2 | Maximum Fe(II) oxidation rates per cell measured in pure cultures and in littoral freshwater lake sediment from microcosm experiments.

\begin{tabular}{|c|c|}
\hline Species/group & $\begin{array}{l}\text { Maximum } \mathrm{Fe}(\mathrm{II}) \text { oxidation } \\
\text { rate }(\mu \mathrm{mol} \mathrm{Fe}(\mathrm{II}) / \\
\left.\text { cell.day }^{-1}\right)\end{array}$ \\
\hline Acidovorax strain BoFeN1 $1^{[1]}$ & $1.0 \cdot 10^{-8}$ \\
\hline Rhodobacter ferrooxidans sp. SW2 ${ }^{[2]}$ & $4.4 \cdot 10^{-10}$ \\
\hline Rhodopseudomonas palustris, strain $\mathrm{TIE}-1^{[3]}$ & $6.6 \cdot 10^{-9}$ \\
\hline Microcosm photoferrotrophs ${ }^{[4]}$ & $5.4 \cdot 10^{-6}$ \\
\hline Microcosm $\mathrm{NO}_{3}^{-}$-reducing $\mathrm{Fe}(\mathrm{II})$-oxidizers ${ }^{[4]}$ & $7.1 \cdot 10^{-6}$ \\
\hline
\end{tabular}

"II Kappler et al. (2005b).

${ }^{12}{ }^{12}$ Hegler et al. (2008).

[3] Jiao et al. (2005).

${ }^{14}$ This study, the maximum Fe(II) oxidation rate was determined from the microcosm incubations; the cell numbers used for the calculation stem from the MPN quantification.

Additionally, phototrophic oxygen production causes day/night fluctuations to the littoral oxygen penetration depth (Gerhardt et al., 2005) and to the nitrate-reducing redox zone (Gerhardt et al., 2010). As ferrous iron is readily oxidized to ferric iron by molecular oxygen (Davison and Seed, 1983), the variable intensity of the oxygen concentration indubitably causes a variation in the ferrous iron concentration, which diffuses upward from deeper sediment layers. During daylight hours, light has been shown to penetrate through sediment up unto a depth of at least 5-6 $\mathrm{mm}$ (Kuehl et al., 1994). However, the sediment investigated in that study exhibited a grain size toward the lower range of that of the Lake Constance sediment. As light penetration depends on the grain size, it is conceivable that light could reach a depth beyond $6 \mathrm{~mm}$ in Lake Constance littoral sediment. This is confirmed by the observation that light exposure of the Lake Constance littoral sediment causes an increase in ferrous iron oxidation up until an approximate depth of $7.5 \mathrm{~mm}$ (Gerhardt et al., 2005). Thus, the light penetration depth intersects both the oxic and the denitrification zone. In this case, the denitrification zone provides ideal conditions for both anaerobic photoferrotrophs and nitrate-reducing iron-oxidizing bacteria. Indeed, the geochemical oxygen profile in combination with the MPN data in a littoral sediment core clearly demonstrated that the photoferrotrophic and nitrate-reducing $\mathrm{Fe}(\mathrm{II})$-oxidizers co-exist below the sedimentary chemocline in the topmost anoxic segment of the sediment (Figure 1). Although this method is restricted in the sense that it cannot directly assess their activity, their presence is an indication that they could be active in this sediment layer. Sharing a habitat poses some serious constraints on their shared substrate requirement and creates a situation where the potential exists for these two groups of bacteria to individually adapt to compete for the limited ferrous iron supply. Considering the variability of the oxygen penetration depth in littoral lake sediment, the microbes catalyzing these anaerobic processes must have developed a way to overcome the spatial changeability of their anoxic habitat beneath the sedimentary chemocline. This can mean a number of things, for instance they could be more tolerant to oxygen than previously considered and possibly even switch to a metabolism that employs $\mathrm{O}_{2}$ as electron acceptor, or have developed a way to move together with the oxygen penetration depth, thus avoiding exposure to oxygen.

\section{Abundance of anaerobic Fe(II)-oxidizing bacteria}

Phototrophic $\mathrm{Fe}$ (II)-oxidizing bacteria have not previously been enumerated in freshwater lake sediments at circumneutral $\mathrm{pH}$. There are many variables that could influence the degree of photoferrotrophic abundance, such as Fe(II) supply and light irradiation. Previously published data only include an MPN study of $\mathrm{Fe}$ (II)-oxidizing phototrophic bacteria in a freshwater town ditch and a freshwater pond. They report numbers between $1.1 \cdot 10^{2}$ and $3.9 \cdot 10^{3}$ cells $\cdot g^{-1}$ dry weight sediment (Straub and BuchholzCleven, 1998), which are lower than the results from this study (Figure 1) by approximately two orders of magnitude. An explanation for this discrepancy could simply be that Lake Constance is a more suitable environment for the photoferrotrophs to thrive in, since it is a more stable environment than the small ditch or pond investigated in the other studies and therefore allows the photoferrotrophs to establish themselves more successfully.

Multiple studies have been conducted on quantifying nitratereducing $\mathrm{Fe}(\mathrm{II})$-oxidizing bacteria in environmental samples (Straub and Buchholz-Cleven, 1998; Hauck et al., 2001; Weber et al., 2006a; Muehe et al., 2009). In Lake Constance, their abundance was quantified in both profundal $\left(1.0 \cdot 10^{4}-5.8 \cdot 10^{5}\right.$ cells $/ \mathrm{mL}$; Hauck et al., 2001) and littoral sediment (at $5 \mathrm{~mm}$ depth; $8 \cdot 10^{3}$ cells $/ \mathrm{mL}$; Muehe et al., 2009). In the current study we counted $2.7 \cdot 10^{4}$ cells $/ \mathrm{mL}$ which lies neatly within range of the previous studies.

Thus, though the littoral Lake Constance photoferrotrophic abundance is slightly higher than measured in previous studies of other environments, nitrate-reducing $\mathrm{Fe}(\mathrm{II})$-oxidizing microorganisms fall within the range of previously quantified cell numbers. To our knowledge, this is the first study which has detected and quantified both groups of bacterial iron oxidation metabolisms in the same sediment layer.

\section{LIMITATIONS OF ANAEROBIC Fe(II) OXIDATION IN ANOXIC SEDIMENTS}

Phototrophic and nitrate-reducing $\mathrm{Fe}$ (II)-oxidizing microorganisms have been formerly studied and cultured in pure cultures (Ehrenreich and Widdel, 1994; Muehe et al., 2009) and enrichments (Straub and Buchholz-Cleven, 1998) but their collective in situ behavior has not previously been monitored in the context of microcosms. Microcosm studies are well suited to investigate substrate limitations imposed on $\mathrm{Fe}$ (II)-oxidizers and thereby the environmental competition pressure for their substrate requirements which control the abundance and activity of the different groups of $\mathrm{Fe}(\mathrm{II})$-oxidizers. Such studies have so far not yet been performed for $\mathrm{Fe}$ (II)-oxidizers. Consequently, there is little known about the limitations the natural environment imposes on their habitat and diet.

\section{Nitrate limitations}

The DOC and aqueous Fe(II) concentration in the pore water of littoral Lake Constance sediment (Table 1) were used to calculate their electron donating capacity, and thus the amount of nitrate that could in theory be reduced. Following this, conclusions were 
drawn on the excess or limitation of nitrate in the natural sediment assuming the following equation applies to all nitrate-reducing iron(II)-oxidizing bacteria:

$$
\begin{aligned}
& 10 \mathrm{Fe}^{2+}+2 \mathrm{NO}_{3}^{-}+24 \mathrm{H}_{2} \mathrm{O} \rightarrow 10 \mathrm{Fe}(\mathrm{OH})_{3}+\mathrm{N}_{2}+18 \mathrm{H}^{+} \\
& \text {(Straub et al., 1996) }
\end{aligned}
$$

The measured dissolved ferrous iron concentration in the pore water of the sediment was $9.8 \mu \mathrm{M}$ (Table 1). As $10 \mathrm{~mol}$ of iron can reduce $2 \mathrm{~mol}$ of nitrate, this amount of iron can reduce $1.96 \mu \mathrm{M}$ nitrate in the sediment. Additional to $\mathrm{Fe}(\mathrm{II})$ oxidation, heterotrophic denitrification is a common process in sedimentary systems which adheres to the following equation:

$2 \mathrm{NO}_{3}^{-}+10 \mathrm{e}^{-}+12 \mathrm{H}^{+} \rightarrow \mathrm{N}_{2}+6 \mathrm{H}_{2} \mathrm{O}$

A concentration of $0.39 \mathrm{mM}$ DOC (Table 1) was measured in the pore water of the lake sediment. As each carbon atom in organic matter/biomass has the capacity to donate approximately four electrons in reduction reactions, the DOC has a theoretical electron donating capacity of $1.56 \mathrm{mM}$ electrons. These electrons can reduce $0.31 \mathrm{mM}$ nitrate to dinitrogen through the process of denitrification. Adding the amount of nitrate that can be reduced through $\mathrm{Fe}(\mathrm{II})$ oxidation and denitrification, $1.96 \cdot 10^{-3}+0.31 \mathrm{mM}$ respectively, a total amount of $3.12 \cdot 10^{-1} \mathrm{mM}$ nitrate could be reduced. As the dissolved nitrate concentration in the sediment pore water is $0.1 \mu \mathrm{M}$ (Table 1), this suggests that the littoral Lake Constance sediment is severely nitrate limited. Considering that probably only a fraction of the DOC is bioavailable, the more than 100-fold excess of electrons from DOC compared to electrons available from $\mathrm{Fe}$ (II) suggests that the reduction of nitrate using electrons from organic matter oxidation is more important in this environment than the oxidation of $\mathrm{Fe}$ (II) coupled to nitrate reduction.

If the sediment is indeed limited in nitrate, the metabolism of the nitrate-reducing Fe(II)-oxidizers might be compromised, which would mean they might not be able to optimally oxidize ferrous iron in natural non-amended sediment. In fact, natural sediment incubated in the dark did not reveal any detectable $\mathrm{Fe}$ (II) oxidation over time (Figure 2A), however, when the sediment was amended with $4 \mathrm{mM}$ nitrate the cells did start to oxidize iron, but only after a lag-phase period of 8 days (Figure 2C). This lack of oxidation in absence of supplementary nitrate addition endorses the hypothesis that the sediment is nitrate limited, as predicted from the previous calculations. This gives phototrophic $\mathrm{Fe}$ (II)-oxidizers a substantial advantage during daylight hours, as adding light to natural sediment evoked an immediate instigation of microbial $\mathrm{Fe}(\mathrm{II})$ oxidation (Figure 2B).

It has previously been reported that most nitrate-reducing $\mathrm{Fe}$ (II)-oxidizers are capable of pure denitrification (Straub et al., 1996, 2004; Muehe et al., 2009), utilizing organic carbon as electron donor. It is possible that the nitrate-reducing Fe(II)-oxidizers employ this system of denitrification in non-amended sediment, thus explaining the lack of $\mathrm{Fe}$ (II) oxidation (Figure 2A). In nitrate amended sediment microcosms incubated under darkness, $\mathrm{Fe}$ (II) oxidation was only initiated after an 8 day lag-phase
(Figure 2C). This suggests that initially denitrification is coupled to the oxidation of organic matter before switching to the oxidation of ferrous iron. It has been shown that the model nitratereducing $\mathrm{Fe}(\mathrm{II})$-oxidizing strain BoFeN1 oxidizes acetate before it utilizes ferrous iron (Kappler et al., 2005b; Chakraborty et al., 2011). When coupling this observation to the results from this study, this suggests that the reduction of nitrate is controlled by a sequential depletion of preferential substrates led by the oxidation of DOC. Furthermore, DOC may be harvested from the environment and stored in internal storage compartments for use during periods of substrate limitation. Such storage compartments have recently been described in the cytoplasm of model organism BoFeN1 (Miot et al., 2011).

Though mixotrophic iron(II)-oxidizers are known to favor a denitrifying metabolism which couples nitrate reduction to organic matter oxidation, addition of ferrous iron to their environment increases their growth yield (Muehe et al., 2009; Chakraborty et al., 2011), thus making mixotrophic iron(II) oxidation a beneficial lifestyle. Apart from mixotrophic iron(II) oxidation, it has been suggested that autotrophic iron(II) oxidation may also be a feasible metabolism. So far, only an autotrophic nitrate-reducing $\mathrm{Fe}$ (II)-oxidizing co-culture has been successfully enriched (Straub et al., 1996; Bloethe and Roden, 2009b) and an isolate is yet to be obtained. As these autotrophic $\mathrm{Fe}$ (II)-oxidizers do not require an organic co-substrate for $\mathrm{Fe}(\mathrm{II})$-oxidation, they theoretically should be able to initiate $\mathrm{Fe}$ (II) oxidation immediately upon incubation for their growth and survival in nitrate amended sediment (Figure 2C). As this did not occur and an isolate has so far not yet been attained and cultured for several generations, this begs the question whether they truly play a significant role in $\mathrm{Fe}$ (II) oxidation at all.

Additionally to being capable of denitrification, some nitratereducing $\mathrm{Fe}(\mathrm{II})$-oxidizing strains are also capable of switching to a microaerophilic metabolism (Benz et al., 1998; Edwards et al., 2003). Though it is still speculative, it is feasible that the nitratereducing $\mathrm{Fe}(\mathrm{II})$-oxidizing bacteria in littoral lake sediments are able to adapt to a microaerophilic $\mathrm{Fe}$ (II) oxidation metabolism during daylight hours in order to successfully compete with the phototrophic $\mathrm{Fe}(\mathrm{II})$-oxidizers for ferrous iron. However, as the microcosm incubation experiments in our study were set-up anoxically, microaerophilic Fe(II) oxidation could not occur. Studying the competition between microaerophilic, nitrate-reducing, and phototrophic $\mathrm{Fe}(\mathrm{II})$-oxidizers in a stratified system during the day-night cycle will be an interesting topic of research in future studies.

The capability to switch to an alternative metabolism is also known for other strains instrumental to the Fe cycle. For instance, Geobacter strains are capable of switching between nitratereducing $\mathrm{Fe}(\mathrm{II})$ oxidation and $\mathrm{Fe}(\mathrm{III})$ reduction (Weber et al., 2006b; Coby et al., 2011) though a lag-phase resulting from the necessity to synthesize proteins for an alternative metabolism has not yet been described in Fe(II)-oxidizing bacteria and it is hitherto unknown if and how this lag-phase manifests itself in the natural environment. The ability to switch between metabolisms may be more widespread and more frequently engaged than previously thought, to maintain a dynamic Fe cycle in environments subjected to constantly changing geochemical parameters. 


\section{Co-substrate limitations}

Many nitrate-reducing $\mathrm{Fe}(\mathrm{II})$-oxidizers require an organic cosubstrate to maintain optimum iron(II) oxidation rates and for continuous growth over several generations (Straub et al., 1996). Many growth experiments necessitate acetate addition to $\mathrm{Fe}$ (II) saturated systems ranging between 0.5 and $2.0 \mathrm{mM}$ acetate per 4-8 mM Fe(II) (Straub et al., 1996, 2004; Kappler et al., 2005b; Muehe et al., 2009). The littoral Lake Constance sediments contain $0.39 \mathrm{mM}$ DOC and 9.8 $\mu \mathrm{M}$ Fe(II) (Table 1). Hence, the sediment contains more organic carbon than $\mathrm{Fe}(\mathrm{II})$, which means nitratereducing Fe(II)-oxidizing bacteria are most probably not limited in the availability of an organic co-substrate required for $\mathrm{Fe}$ (II) oxidation. Consequentially, there is no objection for denitrification to be coupled to organic carbon oxidation which explains why there is a lack of $\mathrm{Fe}$ (II) oxidation in non-amended sediments incubated under darkness (Figure 2A) and why there is an initial lag-phase before $\mathrm{Fe}$ (II) oxidation in dark nitrate amended sediments (Figure 2C). Photoferrotrophs do not require an organic co-substrate since they use $\mathrm{CO}_{2}$ as electron acceptor, therefore they would not be affected by an organic carbon limitation.

\section{Bicarbonate limitations}

To investigate whether phototrophic Fe(II)-oxidizers are subjected to inorganic carbon limitations, set-ups containing either only $10 \mathrm{mM}$ ferrous iron, or $10 \mathrm{mM}$ ferrous iron and $10 \mathrm{mM}$ bicarbonate amendments were set-up (Figure 3). Using the TIC concentration measured in the pore water (Table 1) the amount of bicarbonate in the sediments could be estimated to be $6.26 \mathrm{mM}$. This means that the bicarbonate amended sediments contain roughly three times more bicarbonate than the non-amended sediments. In light set-ups containing ferrous iron amendment, the $\mathrm{Fe}(\mathrm{II})$ oxidation extent was independent from bicarbonate addition. This suggests that photoferrotrophic Fe(II) oxidation is not restricted by the supply of bicarbonate in the sediments, which further suggests that as soon as there is $\mathrm{Fe}(\mathrm{II})$ and light available, phototrophic Fe(II) oxidation will commence immediately, giving them a seemingly unprecedented advantage over the nitrate-reducing iron(II)-oxidizers. Consequently, phototrophic iron oxidation may be of paramount importance to the iron cycle in these littoral freshwater sediments.

\section{THE POTENTIAL FOR COMPETITION BETWEEN NITRATE-REDUCING AND PHOTOTROPHIC Fe(II)-OXIDIZERS}

By quantifying the $\mathrm{Fe}$ (II) oxidation rate per cell per day from pure culture studies and environmentally relevant microcosms, the relative contribution efficiency of the two different metabolic groups of anaerobic $\mathrm{Fe}$ (II)-oxidizing bacteria to overall environmental $\mathrm{Fe}$ (III) formation could be assessed. Additionally, by comparing these oxidation rates and extent of $\mathrm{Fe}$ (III) formation, conclusions on the competition between these two co-existing groups could be evaluated, which has hitherto remained an un-investigated research topic.

\section{Maximum Fe(II) oxidation rates}

It can be expected that the $\mathrm{Fe}$ (II) oxidation rate attained by bacteria cultivated in pure cultures is higher than the rate obtained in environmental systems. In a controlled and optimized laboratory setting they have unlimited access to the nutrients and living space they require to thrive. However, the maximum $\mathrm{Fe}$ (II) oxidation rates calculated from pure culture studies were significantly lower, by two to four orders of magnitude, than those observed in the microcosms with littoral sediments (Table 2). This may be due to an underestimation of the environmental cell numbers owing to limitations affiliated with the MPN method (Cochran, 1950). As a consequence, the $\mathrm{Fe}$ (II) oxidation rate would have been calculated with too few cells, thus obtaining a higher $\mathrm{Fe}(\mathrm{II})$-oxidation rate per cell than is actually achieved. Also, the broader microbial community in the sediment may have a beneficial effect on the $\mathrm{Fe}$ (II) oxidation rates which cannot be obtained by a pure culture; as the littoral sediment has a pore water concentration of $41 \%$ (Table 1 ), it is conceivable that the cells may achieve interspecies communication networks via quorum sensing. The sediments contain mixed interspecies colonies and biofilms of associated microbes that can interact and thus potentially lead to higher Fe(II) oxidation rates than single species can obtain in pure cultures. Moreover, the natural sediment may provide additional micronutrients and vitamins that are central to their growth and survival that are not mimicked in the artificial medium in laboratory experiments with pure cultures. Overall, the nitrate-reducing Fe(II)-oxidizing bacteria seem to exhibit a faster oxidation rate than the photoferrotrophic bacteria in both the pure cultures and the microcosms (Table 2).

\section{Competition dynamics}

Assuming that the light set-up with the original sediment specifically selects the phototrophic Fe(II)-oxidizers (Figure 2B), whilst the nitrate amended dark sediment set-up solely selects the nitratereducing $\mathrm{Fe}(\mathrm{II}$ )-oxidizers (Figure $2 \mathrm{C}$ ), the two curves, modeled based on trendlines, in these separate set-ups exclusively represent these particular anaerobic Fe(II)-oxidizing groups. The set-up that contains both light and nitrate hosts a combination of both the phototrophic and nitrate-reducing $\mathrm{Fe}(\mathrm{II})$-oxidizing groups (Figure 2D). Thus, the superposition of the modeled iron(II) oxidation curves from each individual bacterial group on the Fe(II) oxidation in this particular coupled set-up allows us to draw conclusions on the contribution of each group to the total iron(III) formation (Figure 4). This overlay of the separate roles anaerobic phototrophic and nitrate-reducing $\mathrm{Fe}(\mathrm{II})$-oxidizing bacteria play in Fe(III) formation, shows that the phototrophic model corresponds closely to the $\mathrm{Fe}(\mathrm{III})$ formation over time when both processes can simultaneously take place. The Fe(II) oxidation capacity of the photoferrotrophic microorganisms in littoral freshwater lake sediment is $1.08 \mu \mathrm{mol} F($ II) per day. This could be calculated from the photoferrotrophic $\mathrm{Fe}$ (II) oxidation rate in littoral sediments (Table 2), and the number of photoferrotrophs in the sediment (Figure 1). As the $\mathrm{Fe}(\mathrm{II})$ concentration in the sediment is $9.8 \mu \mathrm{M}$ (Table 1), the photoferrotrophs will deplete the dissolved Fe(II) supply in the sediment within 1 day. Set-ups containing $10 \mathrm{mM} \mathrm{Fe}(\mathrm{II})$ as well as $4 \mathrm{mM}$ supplementary nitrate exhibited the same 8 day lag-phase before initiating $\mathrm{Fe}(\mathrm{II})$ oxidation in dark set-ups (data not shown), and they demonstrated the same instant photoferrotrophic Fe(II) oxidation trend as in sediments only containing additional nitrate in light set-ups. This suggests that independent from the supply of $\mathrm{Fe}$ (II) from deeper sediment 


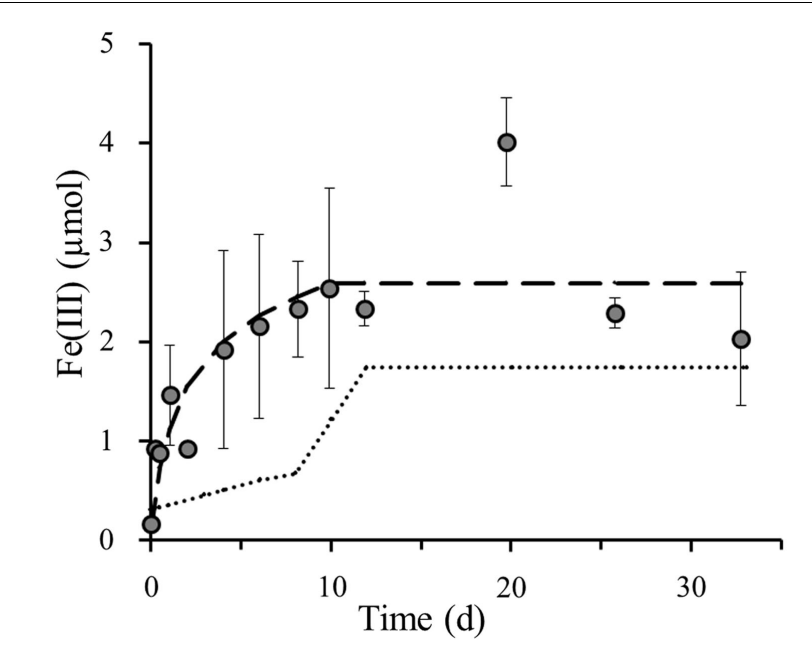

FIGURE 4 | Superposition of poorly crystalline Fe(III) formation ( $y$-axis shows total $\mathrm{Fe}$ (III) content per microcosm set-up) in littoral lake sediments by photoferrotrophs $(=-)$ and nitrate-reducing $\mathrm{Fe}(\mathrm{II})$-oxidizing bacteria (:........) onto measured poorly crystalline $\mathrm{Fe}(\mathrm{III})$ formation $(\mathrm{O})$ in $\mathbf{4} \mathrm{mM}$ nitrate amended sediments incubated under constant light at $23^{\circ} \mathrm{C}$. Error bars indicate minimum and maximum $\mathrm{Fe}(\mathrm{III})$ values from duplicates.

layers and dissolution of $\mathrm{Fe}(\mathrm{II})$-minerals, even though nitratereducing $\mathrm{Fe}(\mathrm{II})$-oxidizing bacteria can start actively respiring iron after 8 days, there will not be sufficient $\mathrm{Fe}(\mathrm{II})$ left for them to respire as the photoferrotrophs will have depleted the Fe(II) supply by then. So even though nitrate-reducing $\mathrm{Fe}(\mathrm{II})$-oxidizers are able to oxidize iron at a higher rate than their phototrophic competitors (Table 2), they are still outcompeted during optimal light and temperature conditions due to substrate limitation. However, even though it is feasible that they should compete with one another for ferrous iron, denitrifiers essentially favor the available organic carbon as electron donor before switching to $\mathrm{Fe}(\mathrm{II})$ oxidation. Therefore, they do not necessarily need to compete with the photoferrotrophs for ferrous iron, because they can also survive on organic carbon. This suggests that the dynamics of nitrate dependent $\mathrm{Fe}$ (II) oxidation, at least in this sediment, are likely regulated by the relative availability of organic matter rather than by the competition with photoferrotrophs for ferrous iron.

\section{Day-night cycle}

Despite the fact that nitrate-reducing $\mathrm{Fe}$ (II)-oxidizers are outcompeted by photoferrotrophs during optimum light conditions, and the nitrate-reducers are limited in nitrate, they are still both found in the upper anoxic sediment layer. Although presence does not necessarily indicate activity, it provides an indication that they could be active, in which case they must have developed a mechanism to cope with the substrate limitations they are subjected to. One possibility is that they are able to co-exist due to the occurrence of the day-night cycle. The oxygen penetration depth in the sediments is heavily influenced by light (Gerhardt et al., 2005), thus the upper anoxic sediment layer shifts according to a day-night rhythm. Additionally, the photoferrotrophs are not able to oxidize ferrous iron at night, simply due to the lack of light. Furthermore, the light penetration depth of the incident light must penetrate beyond the oxygen penetration depth for the anaerobic photoferrotrophs to harvest the light for energy, which has previously been shown to occur in similar sediments (Kuehl et al., 1994). When cloud cover and twilight prevent maximum light irradiation, the photoferrotrophs could possibly survive by converting to chemoheterotrophic growth when organics are present in excess, which has been reported to be possible for at least one photoferrotrophic strain (Jiao et al., 2005). This provides nitrate-reducing $\mathrm{Fe}$ (II)-oxidizers with the upper hand, as they have the opportunity to utilize all the available $\mathrm{Fe}(\mathrm{II})$ after they have consumed the bioavailable carbon, provided this period of heterotrophic nitrate reduction does not take longer than the night and that they are not limited in nitrate. When the sun comes up, the photoferrotrophs immediately take over the dominant role in $\mathrm{Fe}(\mathrm{II})$ oxidation. As many nitrate-reducing $\mathrm{Fe}$ (II) oxidizers are able to switch to a pure denitrifying metabolism (Straub et al., 1996, 2004; Muehe et al., 2009) this leaves the nitrate-reducing $\mathrm{Fe}(\mathrm{II})$-oxidizers to survive on pure denitrification, as long as organic matter and nitrate are simultaneously available. This means that although there is potential for the two $\mathrm{Fe}(\mathrm{II})$-oxidizing groups to directly compete for ferrous iron during optimal light conditions, they are prevented from doing so because their functions are not separated in space as in conventional niche separation, but in time by the day-night cycle. This means that they still fulfill the same function: oxidizing reduced iron(II) beneath the sedimentary oxic-anoxic interface, but the photoferrotrophs perform this function exclusively during the day, whilst nitrate-reducing Fe(II)-oxidizers mostly have the opportunity to execute this at night. Alternatively, the nitratereducing $\mathrm{Fe}(\mathrm{II})$-oxidizing bacteria may compete with the photoferrotrophs during daylight hours by adopting a microaerophilic $\mathrm{Fe}(\mathrm{II})$-oxidizing metabolism once they have exhausted the organic carbon and nitrate supply. By eliminating their nitrate requirement this would allow them to overcome the nitrate limitation imposed on their habitat, thus increasing the probability of success when directly competing with the photoferrotrophs for reduced iron.

When considering all scenarios, a niche separation in time rather than space and the switching from a nitrate-reducing $\mathrm{Fe}(\mathrm{II})$-oxidizing metabolism to a microaerophilic one and the substrate limitations to which the sediment is subjected and combining them altogether, we can speculate on the distribution of the different metabolisms by the two $\mathrm{Fe}(\mathrm{II})$-oxidizing groups of bacteria during daylight and night-time hours (Figure 5). Photoferrotrophs outcompete the nitrate-reducing $\mathrm{Fe}(\mathrm{II})$-oxidizers during daylight hours (Figure 4). Therefore, it is conceivable that the nitrate-reducing $\mathrm{Fe}(\mathrm{II})$-oxidizers abandon this unfruitful method of energy sequestration for either denitrification or microaerophilia. However, as the sediments are severely limited in nitrate (Table 1), it is unlikely that denitrification based on either organic carbon or $\mathrm{Fe}(\mathrm{II})$ oxidation will provide sufficient energy to sustain a bacterial population. Therefore, it is more likely that they are able to compete with photoferrotrophs for $\mathrm{Fe}(\mathrm{II})$ by using oxygen as electron acceptor in a microaerophilic metabolism. At night photoferrotrophic bacteria are unable to metabolize using a photosynthetic based energy source and the oxygen penetration depth lies nearer to the surface in the sediments. The shallowing of the oxygen penetration depth causes an 
upward shift in all the subsequent redox zones. Therefore, the denitrification zone essentially migrates into what was previously the micro-oxic zone (Gerhardt et al., 2010). This provides nitrate to the microaerophilic bacteria, and deprives them of oxygen, providing them with the option to switch back to a nitrate-reducing Fe(II)oxidizing metabolism as they no longer suffer competition pressure from the photoferrotrophs for ferrous iron. Nevertheless, if they are able to harbor motility, it is also possible for them to maintain microaerophilic Fe(II) oxidation as there is still oxygen present in the sediment at night, albeit less and higher up in the sediment than during the day. During the night the photoferrotrophs will probably switch to a chemoheterotrophic metabolism due to the lack of light, requiring organic carbon as substrate. Denitrification coupled to organic carbon oxidation then becomes an unfavorable option for the nitrate-reducing Fe(II)-oxidizers as they would need to compete for organic carbon with the photoferrotrophs. When the sun comes up, the photoferrotrophs are immediately able to oxidize any $\mathrm{Fe}$ (II) present (Figure 2B) and other oxygenproducing phototrophic processes are able to proceed, deepening the oxygen penetration depth. This exposes the nitrate-reducing $\mathrm{Fe}$ (II)-oxidizers to substrate competitors and oxygen, forcing them to switch back to a microaerophilic metabolism in order to sustain $\mathrm{Fe}(\mathrm{II})$-based growth. Moreover, as the daytime microaerophilic oxidation zone during the day coincides with that of nitrate reduction during the night (Figure 5) due to the shifting redox zones, it would be unnecessary for the bacteria to physically move to a different redox zone if they switch their anaerobic metabolism to a microaerophilic one. In fact, bacteria are unable to swim great distances due to buffeting by Brownian motion and their motion path is not straight but curved resulting from a rotating flagellum (Armitage, 1999), reinforcing the hypothesis that switching between metabolisms is a feasible option. Alternatively, they can adopt a denitrifying metabolism, oxidizing organic carbon. This implies that not only their niche for Fe(II) oxidation is organized in a day-night rhythm, their metabolisms are staggered to alternate between organic carbon and ferrous iron oxidation as a strategy to overcome direct competition pressure. Hence, our results suggest that the two iron(II) oxidation processes indeed probably do not need to compete directly with each other, as they are temporally separated by the day-night cycle and due to the fact that the nitrate-reducers preferentially use organic carbon before $\mathrm{Fe}$ (II) as their electron donor.

\section{Seasonal dynamics}

If these two metabolic groups of anaerobic Fe(II)-oxidizers indeed rely on the day-night cycle, then they are also influenced by seasonal oscillations which create longer days as summer progresses, and shorter ones as the winter comes around. Additionally, the light intensity affects the primary productivity of the overall sedimentary microbial community (Overmann and Tilzer, 1989). Previous studies have reported that the ferrous iron concentration also varied throughout the year, being lowest in winter and highest at the end of the summer (Gerhardt et al., 2005). Moreover, Lake Constance hosts an annual spring phytoplankton bloom which generates a large influx of organic carbon into the sediments (Peeters et al., 2007), possibly facilitating the nitrate-reducing $\mathrm{Fe}(\mathrm{II})$-oxidizing communities in the sediments by blocking direct

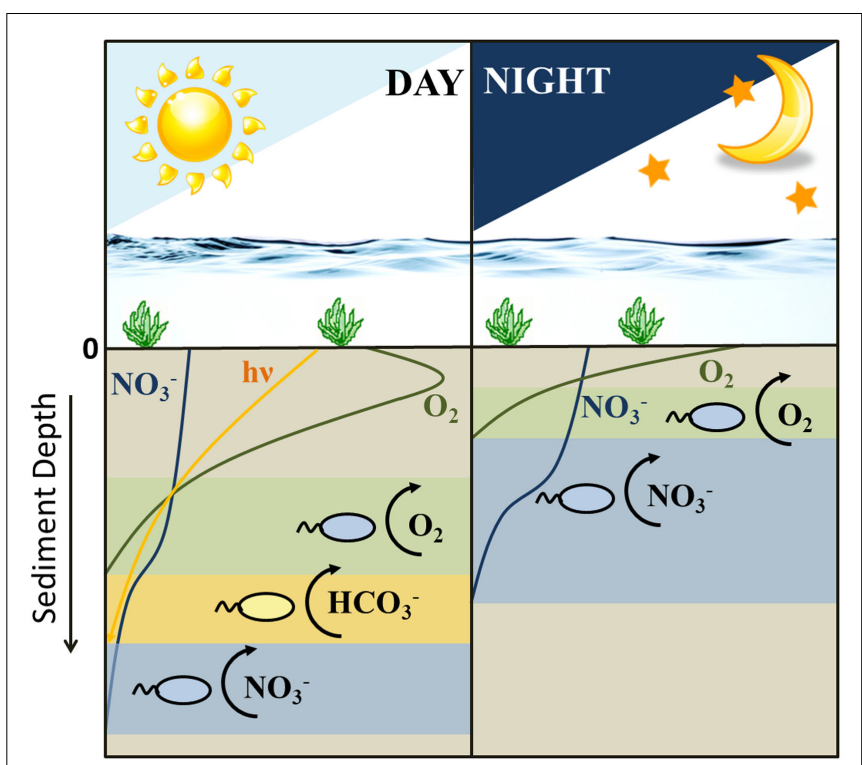

FIGURE 5 | Schematic diagram illustrating the shifting distribution of Fe(II)-oxidizing metabolisms (i.e., varying electron acceptors for ferrous iron oxidation) and the typical depth distribution of oxygen, nitrate, and light during the day/night cycle in littoral freshwater lake sediments. Sediment depth is typically on a $\mathrm{mm}$ scale. During the daytime there are three possible Fe(II)-oxidizing metabolisms active in the sediment column: microaerophiles, photoferrotrophs, and nitrate-reducing Fe(II)-oxidizing bacteria. During the night, Fe(II) can only be oxidized through microaerophilic and nitrate-reducing Fe(II) oxidation.

sunlight in the water column, and providing organic co-substrates to the sediment. Another central variable is temperature, which not only affects biotic activity, but also geochemical parameters such as the solubility of oxygen. It has been reported that photoferrotrophic cultures of KoFox and SW2 are able to oxidize ferrous iron over a wide temperature scale ranging from $5^{\circ} \mathrm{C}$ to $30^{\circ} \mathrm{C}$, with their optimum lying around the $25^{\circ} \mathrm{C}$ (Hegler et al., 2008). This suggests that they might be able to oxidize iron more efficiently during summer when the temperature is higher. As the sediment used in the present study was sampled in winter, it is conceivable that the nitrate and carbon limitations may only be of significant importance during winter. The fact that the variables affecting substrate availability for anaerobic Fe(II) oxidation are controlled by seasonal forcing suggests that seasonal dynamics may play a large role in the co-existence of the microorganisms catalyzing these processes.

\section{CONCLUSION}

Anaerobic nitrate-reducing Fe(II)-oxidizers and photoferrotrophs co-exist in littoral freshwater lake sediments in the topmost anoxic sediment layer directly below the oxygen penetration depth. They share a common ferrous iron substrate requirement that is only present in limited supply, thus creating a situation in which they ought to compete for $\mathrm{Fe}(\mathrm{II})$. However, the results showed that this is not necessarily the case and their ability to co-exist may be attributed to the day-night cycle. Lake Constance's littoral sediments are limited in nitrate, which poses a challenge for nitrate-reducing 
iron(II)-oxidizing bacteria. Nevertheless, nitrate-reducing Fe(II)oxidizers exhibit a faster $\mathrm{Fe}$ (II) oxidation rate both in pure cultures and in the environmental systems (microcosms) than photoferrotrophs. However, during optimal light and substrate conditions they are outcompeted by photoferrotrophic bacteria. Thus, their co-existence may be possible due to a niche separation in time by the day-night cycle, where nitrate-reducing $\mathrm{Fe}(\mathrm{II})$-oxidizers oxidize ferrous iron during darkness and phototrophs play a dominant role in ferrous iron oxidation during daylight. Furthermore, metabolic flexibility of $\mathrm{Fe}$ (II)-oxidizing microbes may play a paramount role in the conservation of the sedimentary iron cycle, as the dynamics of nitrate dependent $\mathrm{Fe}(\mathrm{II})$ oxidation, at least in this sediment, are likely regulated by the relative availability of organic matter rather than by the competition with photoferrotrophs for ferrous iron.

Many open questions remain that invite the opportunity to explore the previously un-investigated co-existence of these two groups of anaerobic $\mathrm{Fe}(\mathrm{II})$-oxidizers. Future studies will monitor nitrate fluctuations in the sediments and elucidate the role of microaerophilic $\mathrm{Fe}(\mathrm{II})$ oxidation in the sedimentary $\mathrm{Fe}(\mathrm{II})$ acquisition simultaneous with photoferrotrophy and nitrate-reducing $\mathrm{Fe}(\mathrm{II})$ oxidation during light conditions. The possibility and

\section{REFERENCES}

Armitage, J. P. (1999). Bacterial tactic responses. Adv. Microb. Physiol. 41, 229-289.

Benz, M., Brune, A., and Schink, B. (1998). Anaerobic and aerobic oxidation of ferrous iron at neutral $\mathrm{pH}$ by chemoheterotrophic nitratereducing bacteria. Arch. Microbiol. 169, 159-165.

Bloethe, M., and Roden, E. E. (2009a). Microbial iron redox cycling in a circumneutral-pH groundwater seep. Appl. Environ. Microbiol. 75, 468-473.

Bloethe, M., and Roden, E. E. (2009b). Composition and activity of an autotrophic $\mathrm{Fe}$ (II)-oxidizing, nitrate-reducing enrichment culture. Appl. Environ. Microbiol. 75, 6937-6940.

Bonneville, S., Van Cappellen, P., and Behrends, T. (2004). Microbial reduction of iron(III) oxyhydroxides: effects of mineral solubility and availability. Chem. Geol. 212, 255-268.

Bruun, A. M., Finster, K., Gunnlaugsson, H. P., Nornberg, P., and Friedrich, M. W. (2010). A comprehensive investigation on iron cycling in a freshwater seep including microscopy, cultivation and molecular community analysis. Geomicrobiol. J. 27, 15-34.

Canfield, D. E. (1989). Reactive iron in marine sediments. Geochim. Cosmochim. Acta 53, 619-632.

Canfield, D. E., and Thamdrup, B. (2009). Towards a consistent classification scheme for geochemical environments, or, why we wish the term

associated lag-phases of the interchanging nitrate-reducing Fe(II)oxidizing or organic carbon-oxidizing and microaerophilic Fe(II)oxidizing metabolisms will also be investigated by surveying and comparing $\mathrm{Fe}(\mathrm{II})$ and DOC oxidation rates. Additionally, knowledge on Fe (II) oxidation in microcosms which are switched between day and night conditions will pose a valuable contribution to getting closer to in situ environmental conditions. Further studies, including seasonality and light iridescence effects, will certainly shed more light on these unknown factors in this fascinating sedimentary system.

\section{ACKNOWLEDGMENTS}

This study was funded by a DFG grant to A. Kappler (KA1736/161), a Marie Curie ERG grant to C. Schmidt (PERF04-GA-2008239252), and a Landesgraduiertenförderung fellowship to E. D. Melton (Gz 1 1.2_7631.2/Melton). Many thanks to Ellen Struve for the TIC and DOC measurements. Thanks to Dr. Heinrich Taubald (University of Tübingen) for XRF analysis of the sediment and Dr. Reiner Ruser (University of Hohenheim) for measuring dissolved $\mathrm{NO}_{3}^{-}$and $\mathrm{NO}_{2}^{-}$concentrations. Last, but not least, we would like to thank the two reviewers for improving the manuscript.

in an Archean Ocean analogue. Proc. Natl. Acad. Sci. U.S.A. 105, 15938-15943.

Davison, W., and Seed, G. (1983). The kinetics of the oxidation of ferrous iron in synthetic and natural waters. Geochim. Cosmochim. Acta 47, 67-79.

Diez, S., Noonan, G. O., Macfarlane, J. K., and Gschwend, P. M. (2007). Ferrous iron oxidation rates in the pycnocline of a permanently stratified lake. Chemosphere 66, 1561-1570.

Druschel, G. K., Emerson, D., Sutka, R., Suchecki, P., and Luther, G. W. (2008). Low-oxygen and chemical kinetic constraints on the geochemical niche of neutrophilic iron(II) oxidizing microorganisms. Geochim. Cosmochim. Acta 72, 3358-3370.

Dudgeon, D., Arthington, A. H., Gessner, M. O., Kawabata, Z. I., Knowler, D. J., Leveque, C., Naiman, R. J., Prieur-Richard, A.-H., Soto, D., Stiassny, M. L. J., and Sullivan, C. A. (2006). Freshwater biodiversity: importance, threats, status and conservation challenges. Biol. Rev. Camb. Philos. Soc. 81, 163-182.

Edwards, K. J., Rogers, D. R., Wirsen, C. O., and McCollom, T. M. (2003). Isolation and characterization of novel psychrophilic, neutrophilic, Feoxidizing, chemolithoautotrophic alpha- and, gamma-Proteobacteria from the deep sea. Appl. Environ. Microbiol. 69, 2906-2913.

Ehrenreich, A., and Widdel, F. (1994). Anaerobic oxidation of ferrous iron by purple bacteria, a new-type of phototrophic metabolism. Appl. Environ. Microbiol. 60, 4517-4526.

Emerson, D., and Moyer, C. (1997). Isolation and characterization of novel iron-oxidizing bacteria that grow at circumneutral pH. Appl. Environ. Microbiol. 63, 4784-4792.

Froelich, P. N., Klinkhammer, G. P., Bender, M. L., Luedtke, N. A., Heath, G. R., Cullen, D., Dauphin, P., Hammond, D., Hartman, B., and Maynard, V. (1979). Early oxidation of organic matter in pleagic sediments of the eastern equatorial atlantic suboxic diagenesis. Geochim. Cosmochim. Acta 43, 1075-1090.

Gerhardt, S., Boos, K., and Schink, B. (2010). Uptake and release of phosphate by littoral sediment of a freshwater lake under the influence of light or mechanical perturbation. $J$. Limnol. 69, 54-63.

Gerhardt, S., Brune, A., and Schink, B. (2005). Dynamics of redox changes of iron caused by light-dark variations in littoral sediment of a freshwater lake. Biogeochemistry 74, 323-339.

Hauck, S., Benz, M., Brune, A., and Schink, B. (2001). Ferrous iron oxidation by denitrifying bacteria in profundal sediments of a deep lake (Lake Constance). FEMS Microbiol. Ecol. 37, 127-134.

Hegler, F., Kappler, A., Posth, N. R., and Jiang, J. (2008). Physiology of phototrophic iron(II)-oxidizing bacteria: implications for modern and ancient environments. FEMS Microbiol. Ecol. 66, 250-260. 
Heising, S., Richter, L., Ludwig, W., and Schink, B. (1999). Chlorobium ferrooxidans sp nov., a phototrophic green sulfur bacterium that oxidizes ferrous iron in coculture with a "Geospirillum" sp strain. Arch. Microbiol. 172, 116-124.

Jiao, Y., Kappler, A., Croal, L. R., and Newman, D. K. (2005). Isolation and characterization of a genetically traceable photoautotrophic $\mathrm{Fe}(\mathrm{II})$-oxidizing bacterium, Rhodopseudomonas palustris strain TIE-1. Appl. Environ. Microbiol. 71, 4487-4496.

Kappler, A., and Newman, D. K. (2004). Formation of $\mathrm{Fe}$ (III)-minerals by $\mathrm{Fe}(\mathrm{II})$-oxidizing photoautotrophic bacteria. Geochim. Cosmochim. Acta 68, 1217-1226.

Kappler, A., Pasquero, C., Konhauser, K. O., and Newman, D. K. (2005a). Deposition of banded iron formations by anoxygenic phototrophic $\mathrm{Fe}(\mathrm{II})$-oxidizing bacteria. Geology 33, 865-868.

Kappler, A., Schink, B., and Newman, D. K. (2005b). Fe(III) mineral formation and cell encrustation by the nitrate-dependent $\mathrm{Fe}$ (II)oxidizer strain BoFeN1. Geobiology 3, 235-245.

Kappler, A., and Straub, K. L. (2005). Geomicrobiological cycling of iron. Rev. Mineral. Geochem. 59, 85-108.

Klee, A. J. (1993). A computer-program for the determination of most probable number and its confidencelimits. J. Microbiol. Methods 18, 91-98.

Konhauser, K. O., Hamade, T., Raiswell, R., Morris, R. C., Ferris, F. G., Southam, G., and Canfield, D. E. (2002). Could bacteria have formed the Precambrian banded iron formations? Geology 30, 1079-1082.

Konhauser, K. O., Kappler, A., and Roden, E. E. (2011). Iron in microbial metabolisms. Elements 7, 89-93.

Kuehl, M., Lassen, C., and Jorgensen, B. B. (1994). Light penetration and light intensity in sandy marine sediments measured with irradiance and scalar irradiance fiber-optic microprobes. Mar. Ecol. Prog. Ser. 105, 139-148.
Larese-Casanova, P., Haderlein, S. B., and Kappler, A. (2010). Biomineralization of lepidocrocite and goethite by nitrate-reducing $\mathrm{Fe}(\mathrm{II})$ oxidizing bacteria: effect of $\mathrm{pH}$, bicarbonate, phosphate, and humic acids. Geochim. Cosmochim. Acta 74, 3721-3734.

Lovley, D. R., Holmes, D. E., and Nevin, K. P. (2004). Dissimilatory Fe(III) and $\mathrm{Mn}(\mathrm{IV})$ reduction. Adv. Microb. Physiol. 49, 219-286.

Lovley, D. R., and Phillips, E. J. P. (1988). Novel mode of microbial energymetabolism - organic-carbon oxidation coupled to dissimilatory reduction of Iron or Manganese. Appl. Environ. Microbiol. 54, 1472-1480.

Macdonald, L. H., Moon, H. S., and Jaffe, P. R. (2011). The role of biomass, electron shuttles, and ferrous iron in the kinetics of Geobacter sulfurreducens-mediated ferrihydrite reduction. Water Res. 45, 1049-1062.

Miot, J., Maclellan, K., Benzerera, K., and Boisset, N. (2011). Preservation of protein globules and peptidoglycan in the mineralized cell wall of nitrate-reducing, iron(II)-oxidizing bacteria: a cryo-electron microscopy study. Geobiology 9, 459-470.

Muehe, E. M., Gerhardt, S., and Kappler, A., and Schink, B. (2009). Ecophysiology and the energetic benefit of mixotrophic $\mathrm{Fe}(\mathrm{II})$ oxidation by various strains of nitrate-reducing bacteria. FEMS Microbiol. Ecol. 70, 335-343.

Overmann, J., and Tilzer, M. M. (1989). Control of primary and the significance of photosynthetic bacteria in a meromictic kettle lake Mittlerer Buchensee, West-Germany. Aquat. Sci. 51, 261-278.

Peeters, F., Straile, D., Lorke, A., and Ollinger, D. (2007). Turbulent mixing and phytoplankton spring bloom development in a deep lake. Limnol. Oceanogr. 52, 286-298.

Posth, N. R., Hegler, F., Konhauser, K. O., and Kappler, A. (2008). Alternating $\mathrm{Si}$ and Fe deposition caused by temperature fluctuations in Precambrian oceans. Nat. Geosci. 1, 703-708.
Poulain, A. J., and Newman, D. K. (2009). Rhodobacter capsulatus catalyzes light-dependent $\mathrm{Fe}(\mathrm{II})$ oxidation under anaerobic conditions as a potential detoxification mechanism. Appl. Environ. Microbiol. 75, 6639-6646.

Rahalkar, M., Deutzmann, J., Schink, B., and Bussmann, I. (2009). Abundance and activity of methanotrophic bacteria in littoral and profundal sediments of Lake Constance (Germany). Appl. Environ. Microbiol. 75, 119-126.

Raven, J. A., and Cockell, C. S. (2006). Influence on photosynthesis of starlight, moonlight, planetlight, and light pollution (reflections on photosynthetically active radiation in the universe). Astrobiology 6 , 668-675.

Schmidt, C., Behrens, S., and Kappler, A (2010). Ecosystem functioning from a geomicrobiological perspective a conceptual framework for biogeochemical iron cycling. Environ. Chem. 7, 399-405.

Sobolev, D., and Roden, E. E. (2002). Evidence for rapid microscale bacterial redox cycling of iron in circumneutral environments. Antonie Van Leeuwenhoek 81, 587-597.

Stookey, L. L. (1970). Ferrozine-a new spectrophotometric reagent for iron. Anal. Chem. 42, 779-781.

Straub, K. L., Benz, M., Schink, B. and Widdel, F. (1996). Anaerobic, nitrate-dependent microbial oxidation of ferrous iron. Appl. Environ. Microbiol. 62, 1458-1460.

Straub, K. L., and Buchholz-Cleven, B. E. E. (1998). Enumeration and detection of anaerobic ferrous ironoxidizing, nitrate-reducing bacteria from diverse European sediments. Appl. Environ. Microbiol. 64 4846-4856.

Straub, K. L., Schoenhuber, W. A., Buchholz-Cleven, B. E. E., and Schink, B. (2004). Diversity of ferrous iron-oxidizing, nitrate-reducing bacteria and their involvement in oxygen-independent iron cycling. Geomicrobiol. J. 21, 371-378.

Thamdrup, B. (2000). Bacterial manganese and iron reduction in aquatic sediments. Adv. Microb. Ecol. 16, 41-84.

Weber, K. A., Pollock, J., Cole, K. A., O'Connor, S. M., Achenbach L. A., and Coates, J. D. (2006a). Anaerobic nitrate-dependent iron(II) bio-oxidation by a novel lithoautotrophic betaproteobacterium, strain 2002. Appl. Environ. Microbiol. 72, 686-694.

Weber, K. A., Urrutia, M. M., Churchill, P. F., Kukkadapu, R. K., and Roden, E. E. (2006b). Anaerobic redox cycling of iron by freshwater sediment microorganisms. Environ. Microbiol. 8, 100-113.

Widdel, F., Schnell, S., Heising, S., Ehrenreich, A., Assmus, B., and Schink, B. (1993). Ferrous iron oxidation by anoxygenic phototrophic bacteria. Nature 362, 834-836.

Xiong, J., Fischer, W. M., Inoue, K., Nakahara, M., and Bauer, C. E. (2000). Molecular evidence for the early evolution of photosynthesis. Science 289, 1724-1730.

Conflict of Interest Statement: The authors declare that the research was conducted in the absence of any commercial or financial relationships that could be construed as a potential conflict of interest.

Received: 14 November 2011; accepted: 14 May 2012; published online: 31 May 2012.

Citation: Melton ED, Schmidt C and Kappler A (2012) Microbial iron(II) oxidation in littoral freshwater lake sediment: the potential for competition between phototrophic vs. nitrate-reducing iron(II)oxidizers. Front. Microbio. 3:197. doi: 10.3389/fmicb.2012.00197

This article was submitted to Frontiers in Microbiological Chemistry, a specialty of Frontiers in Microbiology.

Copyright (C) 2012 Melton, Schmidt and Kappler. This is an open-access article distributed under the terms of the Creative Commons Attribution Non Commercial License, which permits noncommercial use, distribution, and reproduction in other forums, provided the original authors and source are credited. 